\title{
The consecutive disparity of precipitation in conterminous Spain
}

\author{
Javier Martin-Vide ${ }^{1,2}\left(\mathbb{D} \cdot\right.$ Joan-Albert Lopez-Bustins ${ }^{1,2} \cdot$ Marc Lemus $^{1,2} \cdot$ M. Carmen Moreno-Garcia ${ }^{1,2}$. \\ Xavier Balagué ${ }^{\text {}}$ José Carlos Gonzalez-Hidalgo ${ }^{3,4} \cdot$ Santiago Beguería ${ }^{5}$. Dhais Peña-Angulo ${ }^{6} \cdot$ Víctor Trullenque $^{3}$
}

Received: 11 October 2021 / Accepted: 17 November 2021 / Published online: 3 December 2021

(c) The Author(s) 2021

\begin{abstract}
Precipitation irregularity constitutes a constraint for natural systems and socio-economic activities, particularly in waterscarce environments. Standard variability statistics such as the standard deviation, variance, and coefficient of variation do not consider the chronological order of these values. In Climatology, however, the temporal order of meteorological events is a relevant factor that can affect natural and socio-economic systems. In order to evaluate the disparity between consecutive values in precipitation series, we applied the Consecutive Disparity Index $(D)$ to the monthly grid with the highest spatial resolution $(10 \times 10 \mathrm{~km})$ existing in Peninsular Spain for the period December 1915-November 2015. Monthly, seasonal, and annual $D$ values show an increase from north to southwest, especially in July and August. The $D$ values for the month-tomonth correlative series and for monthly mean precipitation reveal a relatively similar pattern. In the latter case, however, the low values are recorded towards southern Spain, following some mountain ranges in the Centre-East of the territory. Monthly, seasonal, and annual precipitation values are also negatively correlated with the corresponding $D$ values.
\end{abstract}

\section{Introduction}

The temporal evolution of a natural variable can be studied in several ways: (1) based upon its variability from the mean; (2) through analysis of the possible linear or nonlinear temporal trends or by comparing the statistics of two or more periods; (3) in some cases as a cyclic, periodic, or autocorrelated phenomenon, among others. Widely used for the former type of analysis are well-known variability statistics such as standard deviation, variance, or the coefficient

Javier Martin-Vide

jmartinvide@ub.edu

1 Climatology Group, Department of Geography, University of Barcelona, Barcelona, Spain

2 Water Research Institute, Unversity of Barcelona, Barcelona, Spain

3 Departamento de Geografía, Universidad de Zaragoza, Zaragoza, Spain

4 Instituto Universitario Ciencias Ambientales (IUCA), Zaragoza, Spain

5 Estación Experimental de Aula Dei, Consejo Superior de Investigaciones Científicas (EEAD-CSIC), Avda. Montañana 1005, 50059 Zaragoza, Spain

6 Instituto Pirenaico de Ecología, Consejo Superior de Investigaciones Científicas (IPE-CSIC), Zaragoza, Spain of variation. However, none of these considers the temporal sequence of the values in the temporal series. For example, the coefficient of variation $(\mathrm{CV})$, which is calculated as the ratio between the standard deviation and the mean, does not include the order of values, because it is not considered by the mean or by the standard deviation.

In terms of the behaviour of a variable in its succession over time, the same values can provide different temporal orders. The variability between one event and the next can impact natural systems, environmental management, agriculture, water supply, renewable electricity production, etcetera. Analysis of the variability between consecutive values in a climatic series is therefore of great interest with regard to understanding their statistical behaviour and climate variability (Moberg et al. 2000; Dai et al. 2019), as well as their effects on natural and human systems (Engeland et al. 2017). The Consecutive Disparity Index, $D$, was proposed as a way to measure serial variability (Martín-Vide 1986). This index has been applied to precipitation analyses for Peninsular Spain and the Catalonia Region at a low spatial resolution (Martín Vide 1987; Burgueño 1991; Lana and Burgueño 2000; Martín-Vide et al. 2001; Martín-Vide 2003; Lopez-Bustins and Lemus-Canovas 2020); the index has also been employed in other fields such as Ecology (Fernández-Martínez et al. 2018). 
In Mediterranean climates, especially within the Mediterranean Basin, precipitation shows high inter-annual variability, with annual coefficients of variation greater than 20\%. This value has been used as a threshold in Peninsular Spain in order to distinguish the Mediterranean climate from a maritime mid-latitude temperate climate, rather than simply using annual precipitation amounts (Martín-Vide 2003). In some parts of the Mediterranean basin, annual precipitation can reach relatively high averages, for instance 800 and $1,000 \mathrm{~mm}$, but the annual coefficient of variation is always higher than $20 \%$. The coefficient of variation in Spain increases from North to South according to the "Mediterranization" of the climate in this same N-S direction (Martín-Vide 2003).

In addition to this high coefficient of variation, sometimes a marked difference can be observed between consecutive years or months. This fact hinders the planning and management of water resources for agriculture, human consumption, etc. A high degree of consecutive disparity also stresses natural systems, especially in ecosystems, vegetation, soil, and carbon storage, as occurs in seasonally dry climates (Rohr et al. 2013; Gessner et al. 2013; Unger et al. 2010; Ferreira da Silva et al. 2020).

The newly developed high-spatial-resolution $(10 \times 10 \mathrm{~km})$ gridded monthly precipitation database MOPREDAS_century (CLICES project, 2021) has recently become available. This dataset, spanning over one century (1916-2015), has enabled analysis at detailed spatial scale of the consecutive disparity between precipitation values over conterminous Spain, a country in which semiarid conditions are prevalent (Lopez-Bustins 2018).

The present paper is organised as follows: Section 2 establishes the objectives and explains the methodology; the data and study area are described in Section 3; the results are provided in Section 4; finally, Section 5 presents the discussion and conclusions.

\section{Objectives and methodology}

\subsection{Objectives}

This study aims to analyse the consecutive disparity of precipitation in peninsular Spain at fine spatial resolution. This resolution will enable us (1) to obtain a detailed spatial picture of the temporal precipitation contrasts between years, seasons, and months; (2) to associate consecutive disparity with geographical factors, specifically latitude and altitude; and (3) to correlate the consecutive disparity with precipitation means.

\subsection{Methodology}

Standard statistics such as the average, standard deviation, variance, and coefficient of variation do not consider the temporal order of the values in a time series. Nonetheless, chronological ordering of the values constitutes an important factor in the temporal behaviour of the analysed variable. Any precipitation series considered in chronological order and the same series sorted in increasing or decreasing order will present the same mean and standard deviation (and, therefore, the same coefficient of variation). Their climatic significance, however, would be very different. There would be a slight consecutive disparity in the ordered series because the differences between successive values would be lower than in the non-ordered series. An example provided highlights the importance of chronological ordering, as well as the limitations of the aforementioned variability statistics in the temporal series of climatic variables. Fig. 1 shows two fictitious short series giving the same values but in a different chronological order.

The two series reveal different temporal behaviour patterns, although the mean $(530 \mathrm{~mm})$, standard deviation $(171.8 \mathrm{~mm})$, and coefficient of variation $(32.4 \%)$ are the same. Series A shows a higher disparity or irregularity between consecutive values than series B. In the first series, a value above average is followed by a lower value and then a higher value, etc. In series B, on the other hand, the low and high values tend to appear together in correlative

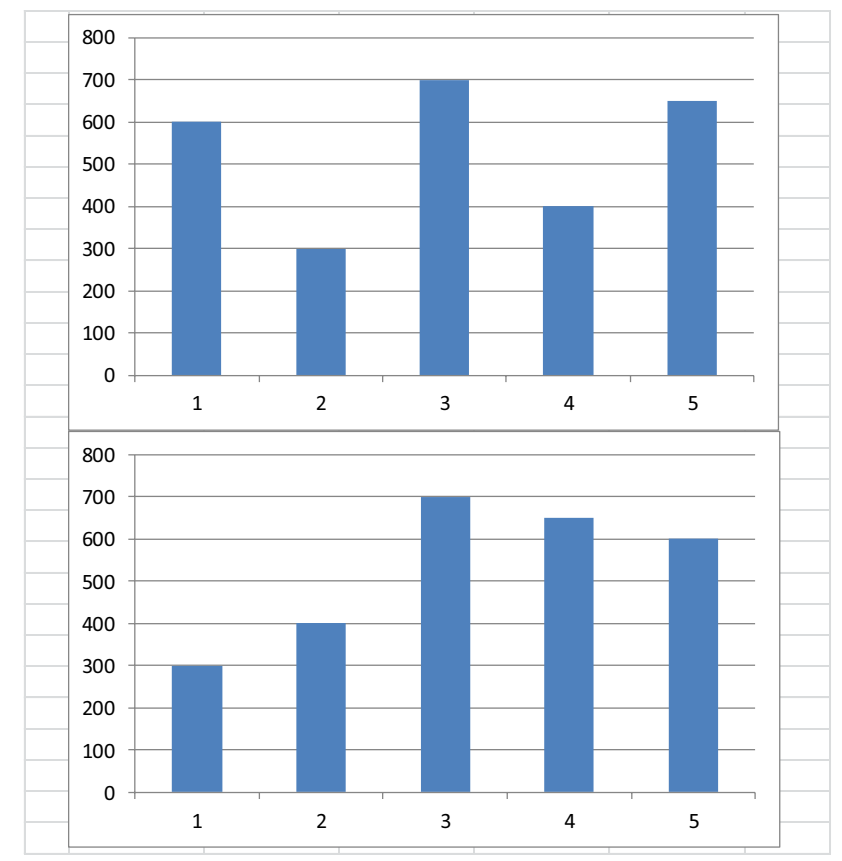

Fig. 1 Two fictitious series (A, up; B, down) with the same mean, variance, and $C V$, and a different $D$ (see text) 
positions. Series A presents greater jumps between consecutive values than series B, i.e. greater consecutive disparity. In order to provide an index sensitive to successive variations in a time series, the Consecutive Disparity Index, $D$ (MartínVide 1986), was proposed as follows:

$D=\frac{1}{n-1} \cdot \sum_{i=1}^{n-1}\left|\ln \frac{p_{i+1}}{p_{i}}\right|$

where $p_{i}$ is the value in position $i$ and $n$ is the series length, $\forall p_{i}, p_{i+1} \neq 0$.

For the example in Fig. 1, the $D$ of series A is 0.65 and the $D$ of series $\mathrm{B}$ is 0.25 . The difference expresses the higher consecutive disparity in series A than in series B.

Several options exist for avoiding numerical indetermination (division by 0 ), when a time series contains zeros (which is common in monthly precipitation data in desertic climates or ones possessing a dry season): to convert the 0 values to a minimal value, for example, $1 \mathrm{~mm}$; to convert the values below $1 \mathrm{~mm}$ to $1 \mathrm{~mm}$; to convert all the small values to 0.01 times the monthly mean; or to add a constant, $c$, that can also be 1 , to all values of the entire time series (Fernández-Martínez et al. 2018), as:

$D=\frac{1}{n-1} \cdot \sum_{i=1}^{n-1}\left|\ln \frac{p_{i+1}+c}{p_{i}+c}\right|$

The $D$ index is always greater than or equal to 0 because it is the average of $n-1$ terms, which are absolute values. And $D=0 \leftrightarrow \mathrm{p}_{\mathrm{i}}=\mathrm{p}_{\mathrm{i}+1} \forall \mathrm{i}$, which is evident.
When comparing $D$ and $C V$ the following relationships are verified:

In a series with mean, $m$, not null

$D=0 \longleftrightarrow C V=0$

which is plain to see: $D=0 \leftrightarrow \mathrm{p}_{\mathrm{i}}=\mathrm{p}_{\mathrm{i}+1} \forall \mathrm{i} \leftrightarrow \mathrm{p}_{\mathrm{i}}=\mathrm{m} \forall \mathrm{i}$ $\leftrightarrow \mathrm{p}_{\mathrm{i}}-\mathrm{m}=0 \forall \mathrm{i} \leftrightarrow \mathrm{s}=\sqrt{\frac{\sum_{1}^{n}\left(p_{i}-m\right)^{2}}{n-1}}=0 \leftrightarrow \mathrm{CV}=0$

Note that, for two series with an equal $C V, D$ does not have to be equal, as exemplified in Fig. 1. Conversely, if the value of $D$ of any two series matches, this does not imply that the $C V$ of the two series has to be the same. For example, the series 100,200 , and $160 \mathrm{~mm}$ and the series 80,100 , and $200 \mathrm{~mm}$ have the same $D=0,46$, while the $C V$ of the former one is $26.8 \%$ and that of the latter one is $41.4 \%$.

Furthermore, $D$ is clearly minimum when the values are sorted in increasing or decreasing order because the jumps will be the smallest. Moreover, $D$ will be the same in both cases because $\left|\ln \frac{a}{b}\right|=\left|\ln \frac{b}{a}\right|$ for any pair of positive real numbers, $a$ and $b$.

Another theoretical property involves the following (Martín Vide 1987):

$$
\text { If } \begin{aligned}
p_{i+1} & =\alpha \cdot p_{i}, \forall i \rightarrow D=|\ln \alpha| \text {, because } D=\frac{1}{n-1} \cdot \sum_{i=1}^{n-1}\left|\ln \frac{p_{i+1}}{p_{i}}\right| \\
& =\frac{1}{n-1} \cdot \sum_{i=1}^{n-1}\left|\ln \frac{\alpha p_{i}}{p_{i}}\right|=\frac{1}{n-1} \cdot(n-1) \cdot|\ln \alpha|=|\ln \alpha|
\end{aligned}
$$

Finally, Lana and Burgueño (2000) generalised the above property as follows:

If $p_{i+1}=p_{i} \cdot(1 \pm(\mu / 100)), \mu<100 \rightarrow D=\sum_{1}^{\infty}\left(\frac{\mu}{100}\right)^{k} / k, \mu<100, k=1 \ldots \infty$

In summary, $C V$ and $D$ have the same range, 0 to $\infty$, and 0 is the value for both parameters when $\mathrm{p}_{\mathrm{i}}=\mathrm{p}_{\mathrm{i}+1}, \forall i$. The $D$ index considers the chronological order of the values in the series, but the $C V$ does not. The $C V$ uses the standard deviation and mean of the series, whereas $D$ employs a logproportional comparison of consecutive series values by means of the absolute value of natural logarithms.

As for the calculations, firstly, $D$ of the January precipitation series, February precipitation series, etc. was calculated inter-annually for each cell of the study area and the entire period, the same for the four seasons, and for the annual precipitation series. Secondly, $D$ was applied to the monthly complete series, starting in December 1915 and ending in November 2015, of each cell. And finally, $D$ was applied to the consecutive monthly means of each cell.

For the statistical computing, graphics, and maps, we used the free $\mathrm{R}$ software with the contour function for mapping (R Core Team 2017).

\section{Data and study area}

\subsection{Data}

We employed the new MOPREDAS_century database version ADW_1, which covers the Spanish mainland. This database was developed within the framework of the CLICES project (Spanish Government, Ministry of Economy and Competitiveness-FEDER, CLICES project, CGL2017-83866-C3-1-R). The dataset covers the December $1915-$ November 2015 period at monthly resolution. It combines observational data from the digitalised archives of the Spanish Meteorological Agency (AEMET) with information dating back to 1915 and which was retrieved from the Annual Books published by the former Meteorological Agency. The dataset includes different stations that provide data which vary both spatially and temporally. The minimum number of stations (675) can be observed in 1939, coinciding with the end of the Spanish Civil War, and the maximum 
number (5,237 stations) is recorded in 1975. Considering these variations, and that approximately $30 \%$ of the series covered less than 10 years, particularly prior to 1950 , in order to calculate the final grid, we applied an approach different from the classical ones. In an attempt to achieve the highest possible spatial density and to use all the information available, rather than reconstructing series for interpolation and gridding, we chose to reconstruct monthly fields following an approach similar to that of reanalysis (Slivinski et al. 2019); additionally, we employed the database for Spanish mainland temperature (MOTEDAS_century) in the same period (González-Hidalgo et al. 2020).

The interpolation model was Angular Distance Weighted (ADW) (Brunetti et al. 2006) and the spatial resolution of the grid is $10 \times 10 \mathrm{~km}$. It comprises 5,236 cells with a total of $6,283,200$ monthly values for the period. The seasonal values and the annual values for the same period were calculated from the monthly ones.

\subsection{Study area}

With the exception of its northern fringe, peninsular Spain presents a Mediterranean climate with many different subtypes resulting from the broad latitudinal and altitudinal ranges and the influence of the Mediterranean Sea to the East. The altitudinal range spans from 0 to almost 3,500 m above sea level. The study area contains several quasi-zonal mountain ranges and an interior plateau $(500-900 \mathrm{~m})$. The annual mean precipitation extremes in Mediterranean Spain are as low as $150 \mathrm{~mm}$ on the Cabo de Gata cape, in the south-eastern extreme, likely the driest place in continental Europe, and over 2,000 $\mathrm{mm}$ in some areas in the western part of the Betic Ranges and the Central Range, which constitute a good barrier against humid Atlantic southwest winds during the winter. Additionally, the northern fringe has a temperate mid-latitude maritime climate, with annual precipitation often exceeding 1,000 m. In some parts of this fringe's western and eastern extremes (Galicia and Basque Country regions), annual mean precipitation is higher than 2,500 $\mathrm{mm}$. In addition to this wide range of annual precipitation values, two clear North-South patterns are observed: one for the annual coefficient of variation and another for the duration of the dry spells, both of which increase in a North-South direction (Martín Vide 2011; Serrano-Notivoli et al. 2017). Moreover, the map of the seasonal precipitation regimes is a complex one, with winter constituting the rainiest season to the West, spring in some inland regions, autumn in the East and two sectors even present summer as the rainiest season in the Eastern Pyrenees and the Southern Iberian Range (Martín Vide and Olcina 2001; De Luis et al. 2010). Finally, with regard to rain intensity and daily precipitation concentration, on the eastern fringe, torrential rainfall and high percentages of annual amount are concentrated in just a few days due to the cyclogenetic influence of the warm waters of the Mediterranean Sea in autumn following a hot and sunny summer (Martín-Vide 2004; Serrano-Notivoli et al. 2018; Lionello et al. 2019).

\section{Results}

\subsection{Inter-annual precipitation disparity}

\subsubsection{Monthly}

The values of $D$ for each month of the year and all the cells of the study area were calculated for the entire period. As mentioned in the methodology section, all values lower than $1 \mathrm{~mm}$, which are relatively frequent in the summer months, were converted to $1 \mathrm{~mm}$ to avoid the mathematical indeterminacy of a quotient with a zero denominator. Fig. 2 shows maps of the $D$ statistic for the 12 months. The spatial continuity of the $D$ values in each month is clear, providing much more regular spatial patterns than the corresponding mean precipitation maps (not shown). In addition, the spatial patterns are quite similar between consecutive months, thus indicating well-defined groups of months coinciding with the seasons.

March, April, and May exhibit low values, with an unequivocal North-South gradient. The lowest values of the year are found in May in the North of the study area. The months of June, July, and August present high values and a more marked gradient, following a general NE-SW direction, with the maximum contrast in August. The highest values of the year are observed in July and August over the Southwest. In September, October, and November, the $D$ values are medium-low, presenting a North/Northeastsouthwest gradient. The values for the winter months are medium, with maximum values in the Southwest and the Northeast in January.

\subsubsection{Seasonal}

Fig. 3 shows the plotted results for the four seasons and for the December 1915-November 2015 period. In spring, the $D$ values are low, the highest value being recorded in the Southeast. The same occurs for autumn, but the highest values are located in the southwest. In winter, the values are low to moderate, with the maxima in the southwest and the Northeast. Finally, in summer, values vary greatly; they are very high in the Southwest and low in the Northeast and the North.

\subsubsection{Annual}

Fig. 4 shows the map of the $D$ value for annual precipitation. A North-South pattern can clearly be observed, with the 

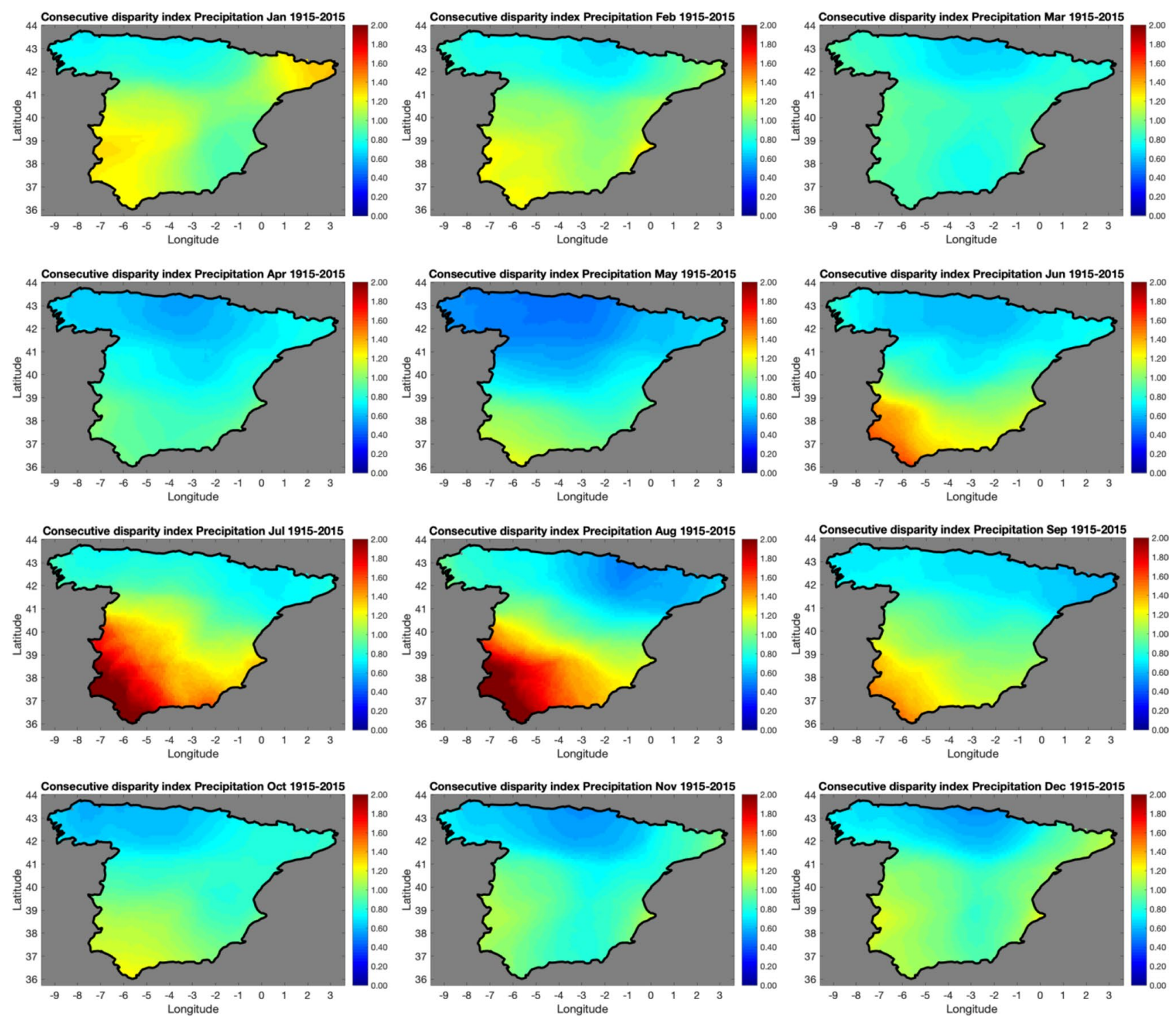

Fig. 2 Inter-annual monthly precipitation $D$ values

maximum values in the Southwest, in the Gulf of Cadiz, and the minimum in the Centre-North, in the Bay of Biscay. The maximum values are close to 0.35 and the minimum value is somewhat higher than 0.15 ; the extreme is 0.16 at $43.38^{\circ} \mathrm{N}$, $2.73^{\circ} \mathrm{W}$ and 0.34 at $36.08^{\circ} \mathrm{N}, 5.53^{\circ} \mathrm{W}$.

\subsection{Monthly precipitation disparity}

The $D$ index can be applied to the series comprising the precipitation of all months over the entire period. These series are made up of 120 (12 months $\times 100$ years) monthly values. In this case, $D$ measures the difference between each month and the following one.

The results of this analysis are shown in Fig. 5. As with the annual $D$ map, the main pattern is N-SW, from less than $0.60\left(0.57\right.$ at $\left.43.38^{\circ} \mathrm{N}, 1.83^{\circ} \mathrm{W}\right)$ to slightly over $1.70(1.71$ at $36.18^{\circ} \mathrm{N}, 5.63^{\circ} \mathrm{W}$ ). As previously stated, many months provide a value of $0 \mathrm{~mm}$, especially in summer in the South of the study area, and all values lower than $1 \mathrm{~mm}$ have therefore been converted to $1 \mathrm{~mm}$ prior to the $D$ calculation.

\subsection{D values of the monthly mean precipitation}

For an intra-annual and averaged analysis, $D$ can be applied to the monthly mean values. In this case, the data involve the 12 monthly mean values for precipitation of the study period. The jump between December and January precipitation was included to convey an idea of circularity. Thus, the calculation is computed over 13 values: $\mathrm{p}_{1}$ is the January mean, $\mathrm{p}_{2}$, the February 

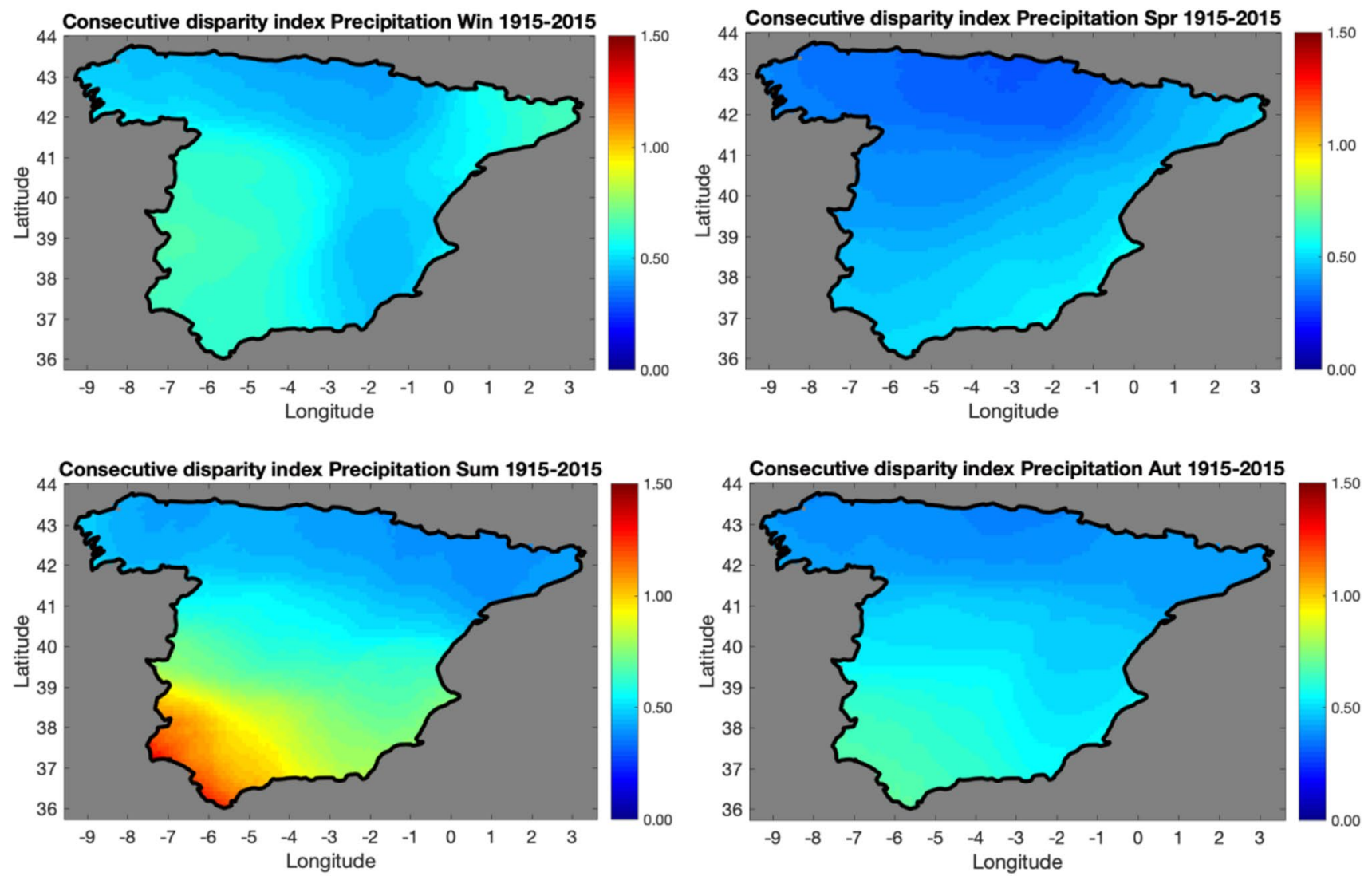

Fig. 3 Inter-annual seasonal precipitation $D$ values
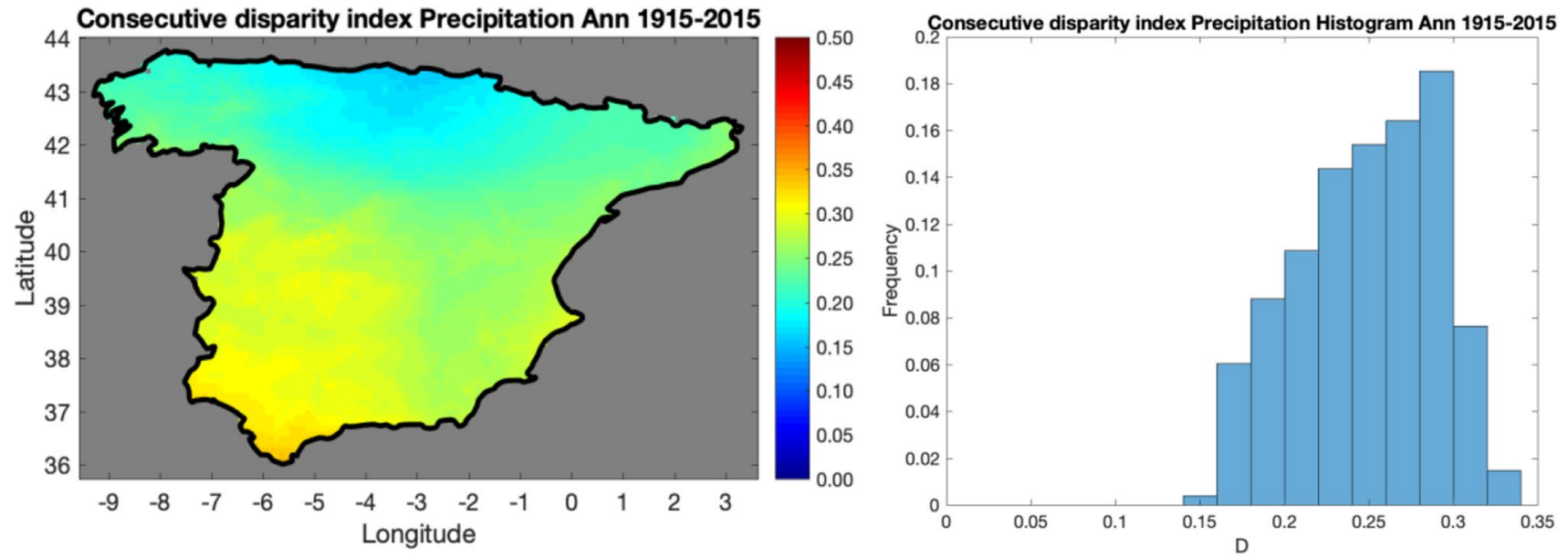

Fig. 4 Annual $D$ values and histogram

mean, ..., $\mathrm{p}_{12}$, the December mean, and $\mathrm{p}_{13}$, the January mean, equal to $p_{1}$. Results are shown in Fig. 6. The pattern is quite different from the previous ones. A ' $\mathrm{V}$ ' shape of low values can be observed with its vertex in the Southeast. The maximum values are located in the southernmost part of the study area. Values range from 0.25 (at $42.58^{\circ} \mathrm{N}$, $1.38^{\circ} \mathrm{E}$ ) to $1.40\left(\right.$ at $\left.36.18^{\circ} \mathrm{N}, 5.63^{\circ} \mathrm{W}\right)$. Note that this last point coincides with the highest correlative month-to-month $D$ value (Fig. 5). It is located very close to the southern extreme of the Iberian Peninsula. 

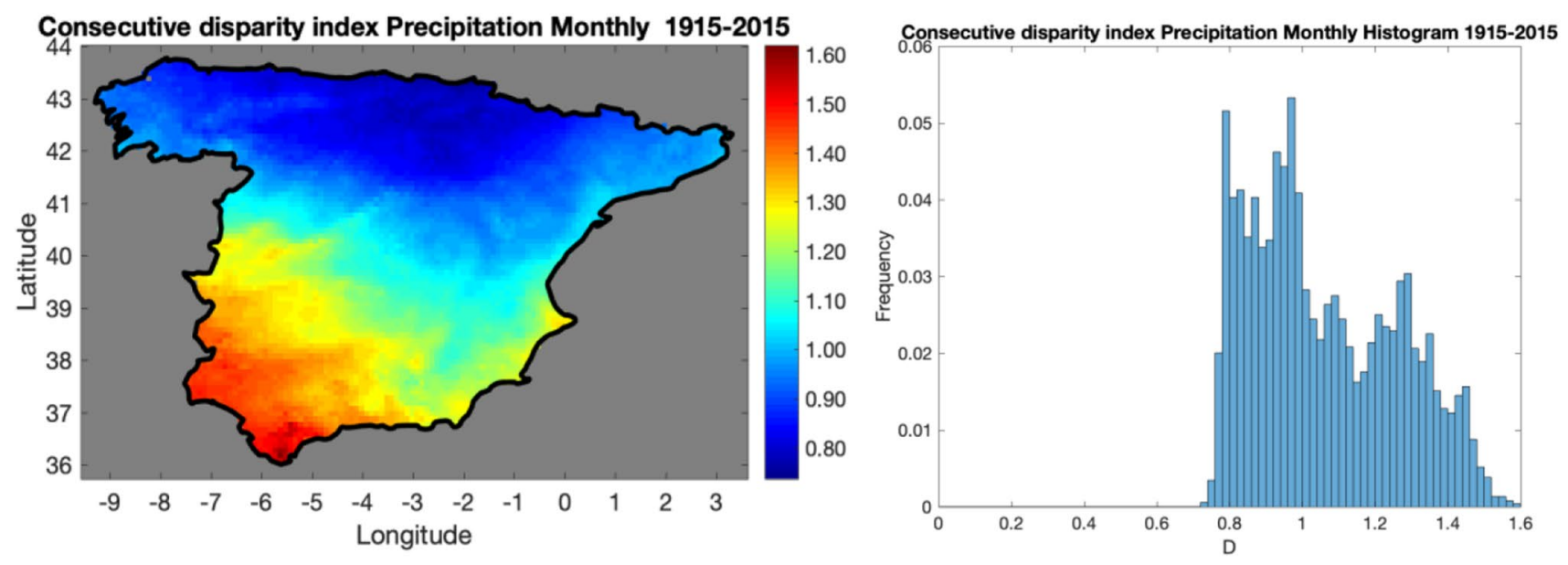

Fig. 5 Monthly precipitation $D$ values and histogram
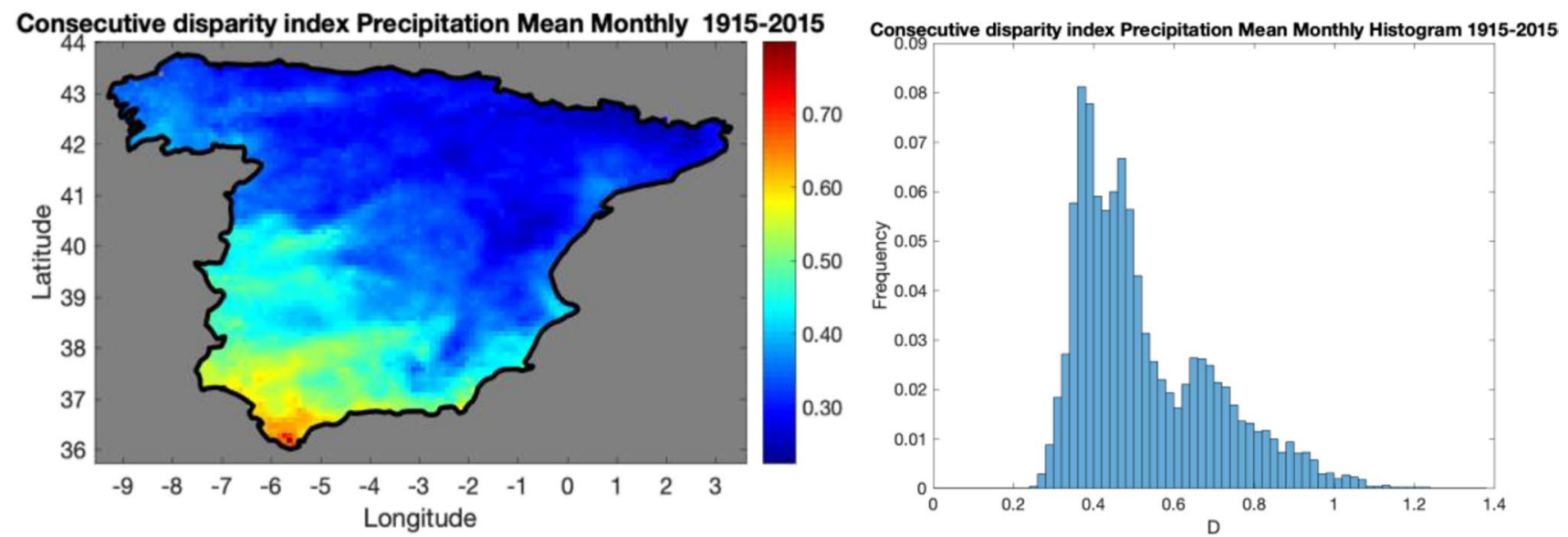

Fig. $6 D$ values of the monthly mean precipitation and histogram

\subsection{Correlation between $D$ and latitude}

All the linear correlations between latitude and monthly, seasonal, and annual $D$ are negatively and statistically significant $(p<0.01)$, meaning that the precipitation regimes in the northern areas are less variable than those in the south. Fig. 7 presents the corresponding seasonal and annual graphs with regression lines $(R=-0.51$ in winter, -0.85 in spring, -0.91 in summer, -0.95 in autumn, and -0.95 annually). By months (not shown), the highest slopes are found in July and August and, by seasons, in summer, corresponding with the $D$ values, which show a big difference between the North and the Southwest. The lowest slope is in March, when the $D$ values are relatively similar throughout the study area.

\subsection{Correlation between $D$ and altitude}

All the linear correlations between altitude and monthly, seasonal, and annual $D$ are not statistically significant ( $p$ $\geq 0.05$ ).

\subsection{Correlations between monthly, seasonal, and annual precipitation and $D$ values}

All the linear correlations by months, seasons, and annually between precipitation and $D$ values are negatively and statistically significant ( $p$-value $<0.001$, except for March, $p$-value $<0.05)$. Fig. 8 shows the plot for annual values $(R=$ $-0.35)$.

\section{Discussion and conclusions}

Evaluation of the differences or jumps between the consecutive precipitation amounts, for instance, the annual amounts, furnishes new information with respect to the standard deviation, variance, or coefficient of variation because these statistical parameters do not take into account the order of series values. The same is true for the contrasts between one specific month or season and the same month or season the 

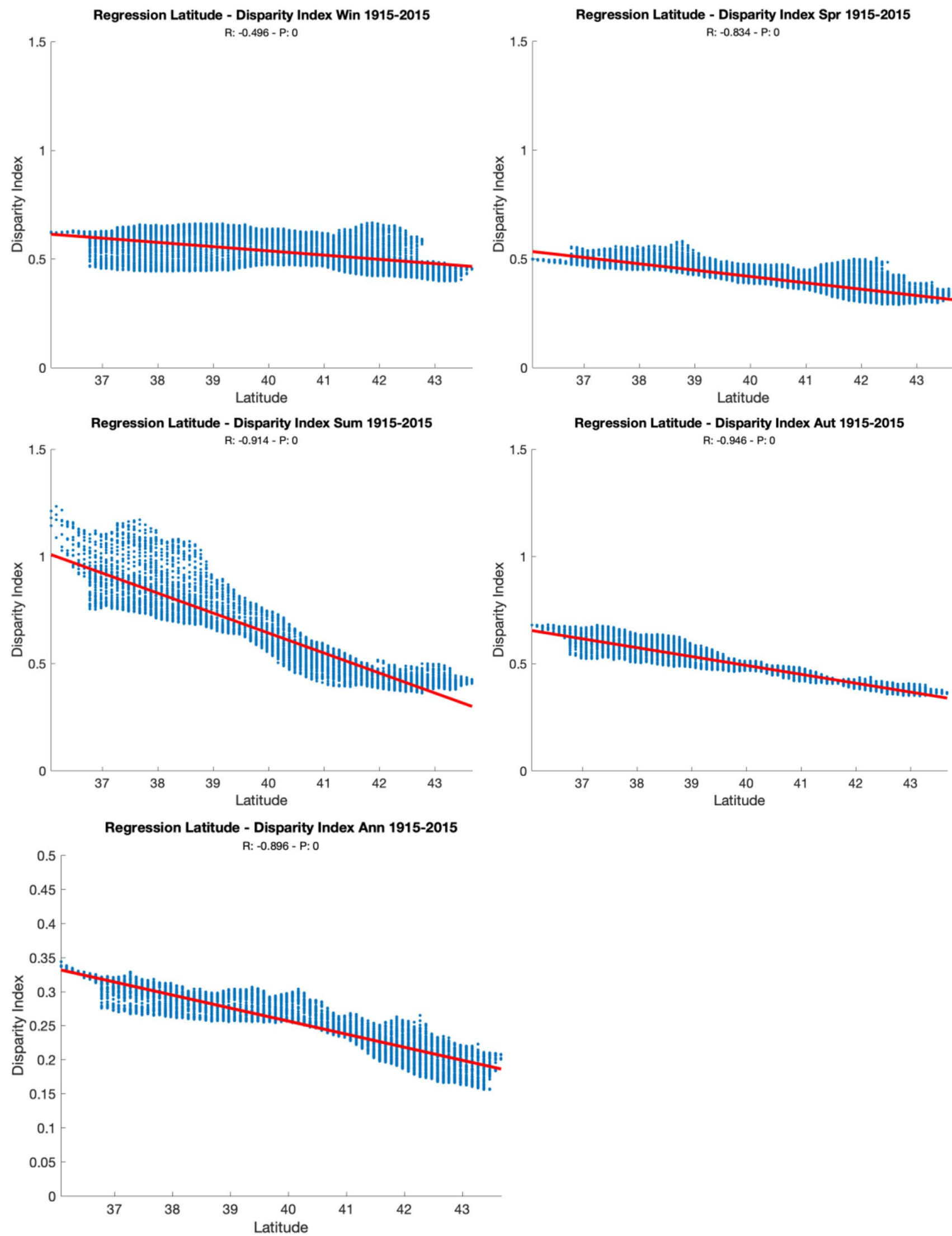

Fig. 7 Correlations between latitude versus seasonal and annual $D$ 
Fig. 8 Correlation between annual precipitation and $D$ values

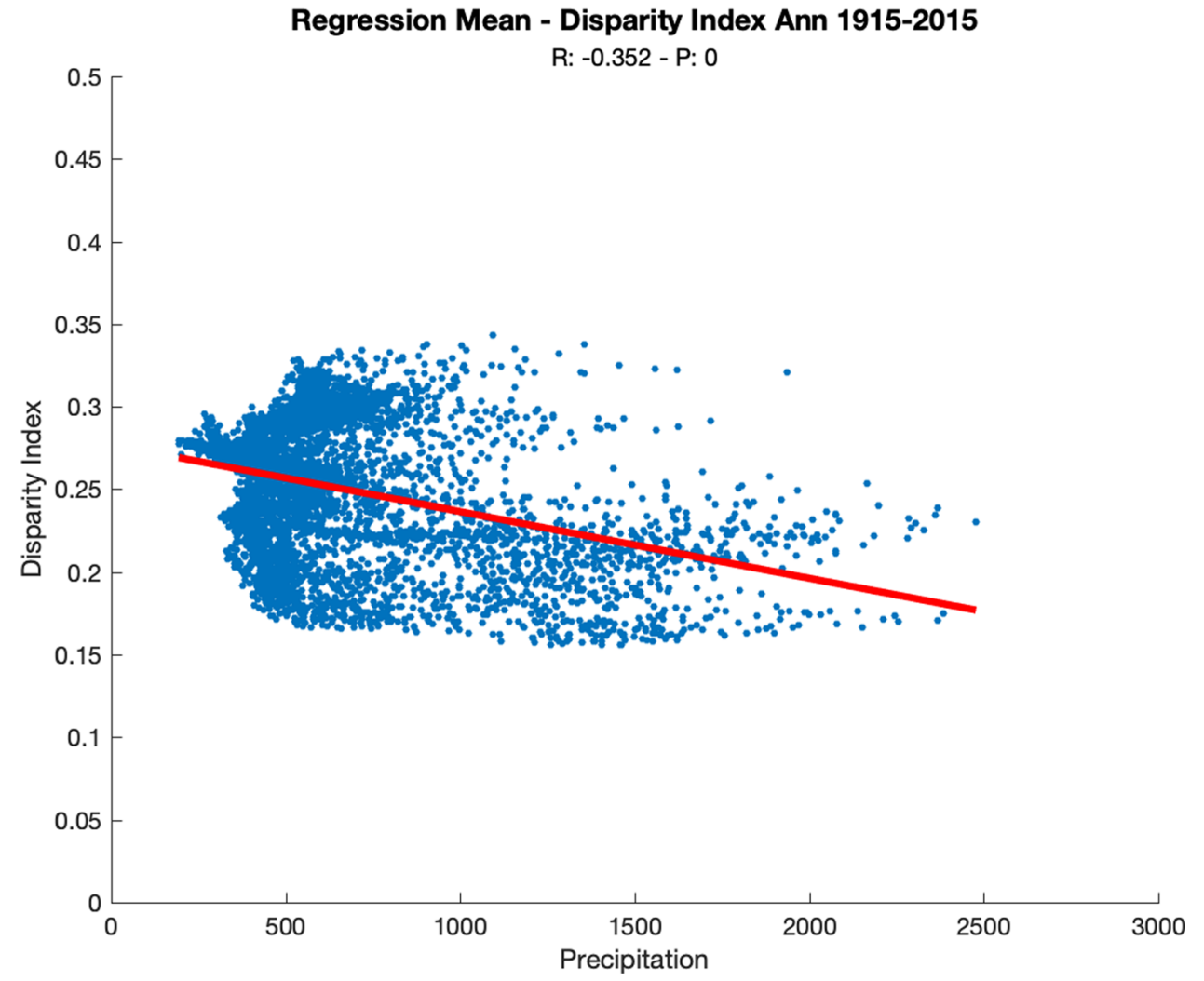

following year, etc., for example, Januaries or summers. The Consecutive Disparity Index, $D$, proposed by Martín-Vide (1986), enables the jumps between correlative values in a series to be quantified. To date, applications of $D$ have been limited to a small amount of papers based on a limited number of series (Martín Vide 1987; Lana and Burgueño 2000; Lopez-Bustins and Lemus-Canovas 2020), as opposed to the present article, involving a high-quality gridded database covering Peninsular Spain at a detailed spatial scale over a long period.

All the $D$ maps obtained show geographic coherence, with well-defined spatial patterns and no artificial shape. Interestingly, the $D$ maps are spatially more regular and smoother than the precipitation amount maps, which reveal numerous rainy cores in the mountains, and dry places in leeward mountains (Atlas Nacional de España 2021). D is correlated with latitude throughout the study area in most applications. This fact is explained by the increase in the irregularity of rainfall from North to South, on moving from a temperate maritime climate at mid-latitudes to a Mediterranean one, with irregular rainfall; this phenomenon becomes more accentuated towards the South (Martín Vide and Olcina 2001).

Correlations for the entire study area between altitude and $D$ are not statistically significant due to the complex distribution of altitudes, despite the regularity of the $D$ patterns. Conterminous Spain possesses mountain ranges with altitudes of over 2,000 $\mathrm{m}$ in the North, centre, South, and East, and being a peninsula, presents coasts practically surrounding the whole territory. In other words, altitude does not correlate with $D$ because in conterminous Spain there is a wide range of elevations both in the northernmost fringe and in the rest, with different climates, maritime mid-latitude and Mediterranean, respectively, that have very different $D$ values. As an example that illustrates the absence of correlation between $D$ and altitude, La Coruña, in the NW, and Malaga, in the $S$, are coastal cities, close to sea level, their $D$ values being as different as 0.18 and 0.36 , respectively. Other geographical factors, such as continentality, appear to significantly affect the $D$ spatial distribution.

The $D$ index offers a new perspective in relation to the precipitation variable. On the one hand, it distinguishes the Mediterranean climate quite well (annual $D>0.20 / 0.25$ in Fig. 4) from the mid-latitude maritime temperate climate (Martín-Vide 2003; Lopez-Bustins and Lemus-Canovas 2020). Although some locations in the Centre and South of the Iberian Peninsula with a Mediterranean climate present high amounts of rainfall, herein the $D$ index is as high as in areas with moderate-to-low amounts. Therefore, the Mediterranean biome is better defined by the temporal irregularity of precipitation, with the long dry period in summer, than by the total precipitation amount. On the other hand, the monthly and seasonal values reveal different behaviour patterns. The summer $D$ values identify the critical area 
very well in terms of quantity and temporal contrast: the Southwest of mainland Spain. Annually, this area of the Gulf of Cadiz presents high $D$ values because some years (and winters) are rainy and others very dry. The rainy years (and winters) are associated with the negative phase of the NAO due to the proximity of the depression of the NAO dipole (Muñoz-Díaz and Rodrigo 2004). On the contrary, during the positive values of the NAO index, the Azores anticyclone protects the SW of the Iberian Peninsula from the Atlantic fronts, and the weather is markedly dry. The high altitudes of Peninsular Spain give rise to a low correlation between the NAO index and precipitation in other parts of the country, especially on the eastern fringe (Martin-Vide and LopezBustins 2006).

From a hydrological point of view, a high inter-annual $D$, as occurs annually in the Southwest and in most of the months and seasons, implies a high risk of water shortages, a fact that characterises the Mediterranean region (Tolika 2019; Zribi et al. 2020). In this sense, $D$ is a good indicator of precarious water resources. On the other hand, there can be abundant rainfall in some months. The binomy drought-heavy rains is characteristic of certain parts of Mediterranean Spain.

The consecutive month-to-month $D$ map resembles the annual $D$ map, with the high values in the same area, the Southwest. In the case of the monthly mean $D$ map, the $\mathrm{V}$-shape showing low values from north to south reflects the continentality of the Centre-East of the Iberian Peninsula. In this area, average precipitation in the winter months is relatively low, and average precipitation in the summer months is not as low as in other sectors as a result of typical summer thunderstorms. Even in the eastern Pyrenees and the south-eastern Iberian Range, the rainiest season is summer (De Luis et al. 2010).

Greater variability of precipitation in many regions as a result of climate change, already observed or projected to occur, is or will be reflected by higher $C V$ values. In the case of precipitation trends, as is beginning to occur in midtemperate maritime zones (increasing precipitation) and in subtropical zones, such as the Mediterranean basin (decreasing precipitation)(IPCC 2021 In Press), $D$ is unlikely to increase much because jumps between one value and the next one are smaller in the ordered series or those presenting a temporal trend. The combination of changes in $C V$ and $D$ could therefore constitute an interesting tool for analysing the changing behaviour of precipitation within a context of climate change.

Acknowledgements Spanish Government, Ministry of Economy and Competitiveness-FEDER, CLICES project (CGL2017-83866-C3-1-R, CGL2017-83866-C3-2-R, CGL2017-83866-C3-3-R).

Water Research Institute, University of Barcelona.

The digitalised data from the Banco Nacional de Datos del Clima were provided by AEMET.
Author contribution Javier Martin-Vide: original idea, conceptualisation, analysis of results, writing-original draft and project administration.

Joan Albert Lopez-Bustins: analysis of results, review and project administration.

Marc Lemus: data curation.

M.Carmen Moreno-Garcia: review and editing.

Xavier Balagué: software, calculations, and visualisation

José Carlos Gonzalez-Hidalgo: data curation, software, and review.

Santiago Beguería: data curation, software, and review.

Dhais Peña-Angulo: data curation, software, and review.

Víctor Trullenque: data curation and software.

Funding Open Access funding provided thanks to the CRUE-CSIC agreement with Springer Nature. Spanish Government, Ministry of Economy and Competitiveness-FEDER, CLICES project (CGL201783866-C3-1-R, CGL2017-83866-C3-2-R, CGL2017-83866-C3-3-R). No other external funding.

Availability of data and materials The data that support the findings of this study are available from the first author, upon reasonable request.

Code availability It is available from the first author, upon reasonable request.

\section{Declarations}

Ethical approval Not applicable

Consent to participate Not applicable

Consent to publish Not applicable

Conflict of interest The authors declare no competing interests.

Open Access This article is licensed under a Creative Commons Attribution 4.0 International License, which permits use, sharing, adaptation, distribution and reproduction in any medium or format, as long as you give appropriate credit to the original author(s) and the source, provide a link to the Creative Commons licence, and indicate if changes were made. The images or other third party material in this article are included in the article's Creative Commons licence, unless indicated otherwise in a credit line to the material. If material is not included in the article's Creative Commons licence and your intended use is not permitted by statutory regulation or exceeds the permitted use, you will need to obtain permission directly from the copyright holder. To view a copy of this licence, visit http://creativecommons.org/licenses/by/4.0/.

\section{References}

Atlas Nacional de España (2021) Clima. In: Atlas Nacional de España. IGN, Madrid http://atlasnacional.ign.es/index.php?title=Clima\& oldid $=27565$

Brunetti M, Maugeri M, Monti F, Nanni T (2006) Temperature and precipitation variability in Italy in the last two centuries from homogenised instrumental time series. Int J Climatol 26:345-381. https://doi.org/10.1002/joc.1251

Burgueño J (1991) Una mesura de la irregularitat de les precipitacions estacionals. Treb Soc Catalana Geog 30:51-61

Dai H, Fan K, Liu J (2019) Month-to-month variability of winter temperature over Northeast China linked to sea ice over the Davis 
Strait-Baffin Bay and the Barents-Kara Sea. J Clim 32(19):63656384. https://doi.org/10.1175/JCLI-D-18-0804.1

De Luis M, Brunetti M, Gonzalez-Hidalgo JC, Longares LA, MartinVide $\mathbf{J}$ (2010) Changes in seasonal precipitation in the Iberian Peninsula during 1946-2005. Glob Planet Chang 74:27-33. https://doi.org/10.1016/j.gloplacha.2010.06.006

Engeland K, Borga M, Creutin JD, François B, Ramos MH, Vidal JP (2017) Space-time variability of climate variables and intermittent renewable electricity production - a review. Renew Sust Energ Rev 79:600-617. https://doi.org/10.1016/j.rser.2017.05.046

Fernández-Martínez M, Vicca S, Janssens IA, Carnicer J, MartínVide J, Peñuelas J (2018) The consecutive disparity index, D: a measure of temporal variability in ecological studies. Ecosphere 9(12):e02527. https://doi.org/10.1002/ecs2.2527

Ferreira da Silva GJ, de Oliveira NM, Santos CAG et al (2020) Spatiotemporal variability of vegetation due to drought dynamics (2012-2017): a case study of the Upper Paraíba River basin, Brazil. Nat Hazards 102:939-964. https://doi.org/10.1007/ s11069-020-03940-x

González-Hidalgo JC, Peña-Angulo D, Beguería S, Brunetti M (2020) MOTEDAS Century: A new high resolution secular monthly maximum and minimum temperature grid for the Spanish mainland (1916-2015). Int J Climatol 40(12):5308-5328. https://doi. org/10.1002/joc. 6520

IPCC, 2021 (In Press) Climate Change 2021: The Physical Science Basis. In: Masson-Delmotte V, Zhai P, Pirani A, Connors SL, Péan C, Berger S, Caud N, Chen Y, Goldfarb L, Gomis MI, Huang M, Leitzell K, Lonnoy E, Matthews JBR, Maycock TK, Waterfield T, Yelekçi O, Yu R, Zhou B (eds) Contribution of Working Group I to the Sixth Assessment Report of the Intergovernmental Panel on Climate Change. Cambridge University Press, Cambridge

Gessner U, Naeimi V, Klein I, Kuenzer C, Klein D, Dech S (2013) The relationship between precipitation anomalies and satellitederived vegetation activity in Central Asia. Glob Planet Chang 110(A):74-87. https://doi.org/10.1016/j.gloplacha.2012.09.007

Lana X, Burgueño A (2000) Some statistical characteristics of monthly and annual pluviometric irregularity for the Spanish Mediterranean Coast. Theor Appl Climatol 65:79-97. https://doi.org/10. 1007/s007040050006

Lionello P, Conte D, Reale M (2019) The effect of cyclones crossing the Mediterranean region on sea level anomalies at the Mediterranean Sea coast. Nat Hazards Earth Syst Sci 19:1541-1564. https:// doi.org/10.5194/nhess-19-1541-2019

Lopez-Bustins JA (2018) Lluvias fuertes, pero mal repartidas. El caso del clima mediterráneo. Biblio 3w XXIII:1243

Lopez-Bustins JA, Lemus-Canovas M (2020) The influence of the Western Mediterranean Oscillation upon the spatio-temporal variability of precipitation over Catalonia (northeastern of the Iberian Peninsula). Atmos Res 236:104819. https://doi.org/10. 1016/j.atmosres.2019.104819

Martín-Vide J (1986) Notes per a la definició d'un índex de «desordre» en pluviometria. Treb Soc Catalana Geog 7:89-96

Martín Vide J (1987) Propiedades y aplicaciones de un índice de disparidad en pluviometría. In: X Congreso Nacional de Geografía. I, A.G.E, Zaragoza, pp 267-276

Martín Vide J, Olcina J (2001) Climas y tiempos de España. Alianza Editorial, Madrid

Martín-Vide J (2003) El tiempo y el clima. Rubes, Barcelona

Martín-Vide J (2004) Spatial distribution of daily precipitation concentration index in Peninsular Spain. Int J Climatol 24:959-971. https://doi.org/10.1002/joc.1030
Martin-Vide J, Lopez-Bustins JA (2006) The Western Mediterranean oscillation and rainfall in the Iberian Peninsula. Int J Climatol 26:1455-1475. https://doi.org/10.1002/joc.1388

Martín-Vide J, Prohom M, Bohigas M, Peña JC, Esteban P, Montserrat D (2001) Índices de irregularidad temporal y dimensión fractal de la precipitación anual en España. In: Pérez-Cueva AJ, López Baeza E, Tamayo J (eds) El Tiempo del Clima. Publicaciones de la Asociación Española de Climatología (AEC) Serie A, 2, Buñol, pp 157-166

Martín Vide J (2011) Estructura temporal fina y patrones espaciales de la precipitación en la España peninsular. Memorias de la Real Academia de Ciencias y Artes de Barcelona LXV(3):1030 pp 119-162

Moberg A, Jones PD, Barriendos M, Bergström H, Camuffo D, Cocheo C, Davies TD, Demarée G, Martin-Vide J, Maugeri M, Rodríguez R, Verhoeve T (2000) Day-to-day temperature variability trends in 160-to 275-year long European instrumental records. J Geophys Res 105(D18):22849-22868. https://doi.org/10.1029/2000J D 900300

Muñoz-Díaz D, Rodrigo F (2004) Impacts of the North Atlantic Oscillation on the probability of dry and wet winters in Spain. Clim Res 27:33-43. https://doi.org/10.3354/cr027033

R Core Team (2017) R: A language and environment for statistical computing. R Foundation for Statistical Computing, Vienna URL https://www.R-project.org/

Rohr T, Manzoni S, Feng X, Menezes R, Porporato A (2013) Effect of rainfall seasonality on carbon storage in tropical dry ecosystems. J Geophys Res Biogeo Sci 118(3):1156-1167. https://doi.org/10. 1002/jgrg.20091

Slivinski LC, Compo GP, Whitaker JS et al (2019) Towards a more reliable historical reanalysis: improvements for version 3 of the Twentieth Century Reanalysis system. Q J R Meteorol Soc 145(724):2876-2908. https://doi.org/10.1002/qj.3598

Serrano-Notivoli R, Beguería S, Saz MA, Longares LA, De Luis M (2017) SPREAD: A high-resolution daily gridded precipitation dataset for Spain - an extreme events frequency and intensity overview. Earth Syst Sci Data 9(2):721-738. https://doi.org/10.5194/ essd-9-721-2017

Serrano-Notivoli R, Martín-Vide J, Saz MA, Longares LA, Beguería S, Sarricolea P, Meseguer-Ruiz O, De Luis M (2018) Spatio-temporal variability of daily precipitation concentration in Spain based on a high-resolution gridded data set. Int J Climatol 38(S1):e518e530. https://doi.org/10.1002/joc.5387

Unger S, Máguas C, Pereira JS, David TS, Werner C (2010) The influence of precipitation pulses on soil respiration - assessing the "Birch effect" by stable carbon isotopes. Soil Biol Biochem 42(10):1800-1810. https://doi.org/10.1016/j.soilbio.2010.06.019

Tolika K (2019) On the analysis of the temporal precipitation distribution over Greece using the Precipitation Concentration Index (PCI): annual, seasonal, monthly analysis and association with the atmospheric circulation. Theor Appl Climatol 137(12):23032319. https://doi.org/10.1007/s00704-018-2736-6

Zribi M, Brocca L, Tramblay Y, Molle F (2020) Water resources in the Mediterranean Region. Elsevier, Amsterdam

Publisher's note Springer Nature remains neutral with regard to jurisdictional claims in published maps and institutional affiliations. 